\title{
Cenzura polityczna wobec karykatury. Doświadczenia francuskie II połowy XVIII i pierwszej połowy XIX wieku. Przyczynek do walki o wolność słowa
}

Ekspresja artystyczna towarzyszy - jak się wydaje - człowiekowi od zarania dziejów. Sztuka stanowiła zawsze immanentną część kultury i cywilizacji. Bez sztuki bardzo trudno byłoby zrozumieć nie tylko życie prywatne w poszczególnych epokach, dzieje kultury, ale nawet historię gospodarczą i polityczną. Sztuka zdaje się nie znać granic geograficznych i chronologicznych. Stale poszerza swój zasięg obejmując kulturę, religię, systemy polityczne, zawłaszcza gospodarkę, stymulując zachowania rynkowe, tworząc nowe zawody, zapewniając utrzymanie rzeszom pracowników, którzy wprawdzie sami sztuki nie tworzą, ale nią administrują, konserwują jej dzieła, zbierają związane z nią przekazy, handlują nimi. Praktycznie od początku swojego istnienia sztuka wydaje się być związana $\mathrm{z}$ religią, którą częstokroć wyraża, oraz z prawem. To ostatnie stara się z jednej strony zdefiniować pojęcie sztuki, z drugiej wyznaczyć jej granice. Przekonaniu artystów, że sztuka jest wolna i nie podlega żadnej reglamentacji towarzyszą stale podejmowane próby wyznaczenia dopuszczalnych prawnie sposobów i form ekspresji. W gruncie rzeczy od starożytności po dzień dzisiejszy zauważyć można mniej lub bardziej świadomą walkę o wolność sztuki. Motywy, jakimi kierują się władze publiczne, starając się swobodę tę ograniczyć mają różne źródła i same przez się zasługują na pogłębioną analizę socjologiczną. Najczęściej wynikają z przyczyn religijnych, osadzone są w pewnych schematach kulturowych, przyzwyczajeniach estetycznych. Według teologów i kapłanów reprezentujących różne religie, sztuka może obrażać uczucia religijne wiernych, podważać dogmaty, ośmieszać symbole. Zdaniem polityków, zwłaszcza w systemach autorytarnych, 
sztuka winna służyć państwu, zmierzać do konsolidacji jego obywateli, wyrażać treści aprobowane przez rządzących. W myśl tej koncepcji artysta powinien identyfikować się z reżimem politycznym, służąc mu wiernie i z przekonaniem. Oczywiście są całe rzesze artystów, często niezwykle utalentowanych, którzy gotowi są spełnić zapotrzebowanie czynników religijnych bądź politycznych, tworzyć na zamówienie, które chociaż bywa określane mianem zamówienia społecznego, jest $\mathrm{w}$ istocie zamówieniem, które wypływa $\mathrm{z}$ kanonów estetycznych, przyjętych za właściwe przez zwierzchników politycznych bądź religijnych. Kanony te, z racji posiadanej władzy, potrafią oni narzucić społeczeństwu jako jedynie możliwe do akceptacji ${ }^{1}$.

Twórczość artystyczna charakteryzuje się jednak tym, że nie daje się łatwo wtłoczyć w ramy schematów. Artyści zwykle wyprzedzają swoją epokę i to czasem o wiele lat. Dzieła, które tworzą prowokują, częstokroć szokują, godzą w przyzwyczajenia. Artysta wyrażając swoje przeżycia, dając upust żywionym uczuciom, chce jednak zdobyć uznanie społeczeństwa, przekonać do prezentowanej wizji, czasem narzucić swój odbiór rzeczywistości. Poeta i powieściopisarz może przez lata pisać do przysłowiowej „szuflady”, nie mając widoków na publikację swoich dzieł - chociaż dzisiaj, w dobie internetu możliwa okazałe okazało się udostępnienie takich utworów w formie elektronicznej. Rzeźbiarz, malarz, twórca filmowy, pożąda publiczności, w ekshibicjonistyczny sposób obnaża swoje uczucia, z wewnętrznym masochizmem spodziewając się bicza krytyki - licząc jednak, że jego duchowe cierpienie nie będzie daremne, że przekona do swoich wizji artystycznych.

Praktycznie od początków istnienia ludzkości wszystkie zjawiska życia społecznego podlegają nieustannej ocenie dokonywane z punktu widzenia rozmaitych grup społecznych i jednostek. Wiele $z$ tych ocen ma charakter aprobatywny - te, jeśli dotyczą sfer: polityczne, ekonomicznej bądź prawnej - skłonni jesteśmy zaliczyć do propagandy politycznej, którą dziś zwykło się sprzedawać w nowym opakowaniu, jako public relations. Znacznie ciekawsze wydają się jednak wypowiedzi negujące wartość jakiś zjawisk społecznych, zmierzające do wykazania ich szkodliwości, bezwartościowości i absurdalności. Utwór satyryczny - nader często występujący w języku potocznym jako „satyra” - to przekaz najczęściej literacki (chociaż nie tylko), wyrażający krytyczne stosunek twórcy do rozmaitych zjawisk życia społecznego, w tym w szczególności - politycznego. Satyryk nie tai, iż zamiarem jego jest ośmieszenie jakichś sytuacji, postępowanie poszczególnych

1 J. Sobczak, Wolność sztuki, twórczości artystycznej, satyry. Czy istnieje kontratyp sztuki? Regulacje europejskie a rozwiazania polskiego systemu prawnego, [w:] J. Jaskiernia (red.), „Uniwersalny i regionalny wymiar praw ochrony człowieka. Nowe wyzwania, nowe rozwiązania”, t. 3, Warszawa 2014, s. 360-370. 
ludzi bądź całych grup społecznych, poddanie krytyce zwyczajów, obyczajów, postaw światopoglądowych, artystycznych, napiętnowanie wad i przywar ${ }^{2}$. Wyjątkowo wdzięcznym obiektem działań satyrycznych staje się polityka i politycy. Im bardziej ci ostatni gotowi traktować się serio, tym chętniej, celniej i z większą zjadliwością gotowi uderzać w nich satyrycy. W literaturze podkreśla się, że istotą wypowiedzi satyrycznych jest negacja - chętnie posługująca się środkami komicznej deformacji: groteską, dowcipem, ironią, kpiną i szyderstwem. Twórca satyry pozornie nie przedstawia wzoru pozytywnego, nie formułuje programów, nie wskazuje ideałów, nie określa wzorów i standardów ${ }^{3}$. Niemniej program pozytywny wbrew pozorom w satyrze także istnieje, ale na ogół jest on głęboko ukryty. To raczej odbiorca utworu satyrycznego ma niejako samodzielnie, przyjmując za swoje negatywne oceny twórcy satyry dojść do aprobowanych - choć nie formułowanych bezpośrednio przez satyryka wniosków. Na tym właśnie zasadza się moc satyry, na tym polega jej niebezpieczeństwo dla jednostek i grup osób, które stały się obiektem satyrycznego przekazu - żeby nie powiedzieć: ataku. Dlatego też utwory satyryczne tak chętnie odbierane są przez społeczeństwo i z taką zajadłością zwalczane przez tych, którzy zostali dotknięci ich ostrzem ${ }^{4}$.

Zjawisko satyry pojawia się już w głębokiej starożytności, a utwory satyryczne pisano nawet w starożytnej Grecji ${ }^{5}$. Do XVIII wieku satyra była traktowana

2 I.I.H. Dee, Satyra jako gra retoryczna, [w:] „Nowa proza amerykańska. Szkice krytyczne”, Warszawa 1983, s. 38; J. Elsberg, Woprosy tieorii satiry, Moskwa 1957, passim.; Literatura polska. Przewodnik encyklopedyczny, T. II, Warszawa 1985, s. 338.

${ }^{3}$ M. Głowiński, A. Okopień-Slawińska, J. Sławiński, Zarys teorii literatury, Warszawa 1986, s. 436-438; A. Bereza, Problemy teorii stylizacji w satyrze, Warszawa 1966, s.17 i n.; R.C. Elliot, The Power of Satire, Princeton 1960, passim; G. Mighet, The Anatomy of Satire, Princeton 1962, passim.

4 J. Sobczak, Ramy prawne satyry politycznej, [w:] A. Grzegorczyk, J. Grad (red.), „Fenomen radości”, Poznań 2007, s. 209-240.

${ }^{5}$ Komedie Arystofanesa stanowią typ zjadliwej satyry politycznej, a dzieła Meniposa z Gadary - satyry wymierzonej w wierzenia religijne i urządzenia społeczne. Pojęciem ,satyra” (saturae) jako pierwszy posłużył się Quintus Ennius na przełomie III i II w. p. n. e. Za właściwego twórcę tego gatunku w literaturze rzymskiej uważa się jednak Calusa Lucyliusa, autora zbioru Saturarum libri, który ustalił charakter i miarę wierszowaną. Utwory Lucyliusza - gorzkie i niekiedy złośliwe, osobiste $\mathrm{w}$ treści - wymierzone były w polityczno-społeczne nieprawidłowości. To dzięki niemu satyra rzymska stała się odrębną formą gatunkową, przybierając charakter: „pouczającego lub napastliwego utworu wierszowanego o własnych rygorach kompozycyjnych, stylistycznych i wersyfikacyjnych, będącego monologiem, dialogiem lub narracją na tematy obyczajowe, polityczne lub literackie”. J. Krzyżanowski, Cz. Hernas (red.), Literatura polska, Warszawa 1985, s. 338. Przedstawicielami satyry rzymskiej byli Marek Terentius Varro, Quintus Horatius Flaccus, Decimus Junius Juvenalis. Satyra odznaczała się na początku rozmaitością formy. Od czasów Horacego zasadniczo jednak ujmowana była w miarę heksametru. Por. M. Geier, Z czego śmieją się mądrzy ludzie, mała filozofia humoru, Kraków 2007, s. 11-98; S. Kierkegaard, O pojęciu ironii z nieustajacym odniesieniem do Sokratesa, Warszawa 1999, s. 19; W. Süß, Lachen, Komik und Witz in der 
jako odrębny gatunek literacki, „pozostając poza klasyfikacją genealogiczną, we wszystkich typach ekspresji nie mieszczących się w tym gatunku"'. Ujmując satyrę jako gatunek literacki nie zajmowano się karykaturą, którą słusznie traktowano jako formę przekazu wizualnego. Nie dostrzegano przy tym tego, że mieści się ona w przekazie satyrycznym. Współcześnie satyra nie stanowi już odrębnego rodzaju ani gatunku literackiego. Może pojawiać się zarówno w wypowiedziach lirycznych, epickich, utworach dramatycznych, zwłaszcza w komediach, poematach, opowiadaniach, bajkach, epigramatach, felietonach, szopkach, monologach, skeczach, kupletach, piosenkach i w tzw. „kawałach” i oczywiście w formie karykatury w rysunkach, grafice, rzadziej w obrazach olejnych bądź akwarelach ${ }^{7}$.

Od lat trwają spory o definicję satyry ${ }^{8}$, chociaż współczesne encyklopedie i słowniki formułują ją w zbliżony sposób ${ }^{9}$. W jednej z niewielu teoretycznych

Antike, Zürich-Stuttgart 1969; G. Fink (red.), Götter, Spötter und Verrückte. Antike Anekdoten, Frankfurt a. M.-Leipzig 1995; J. Bremmer, Witze Spaßmacher und Witzbücher in der antiken griechischen Kultur, [w:] J. Bremmer, H. Roodenburg (red.), „Kulturgeschichte des Humors. Von der Antike bis heute", Darmstadt 1999, s. 18-31; K. Werner Weber, Humor in der Antike, Stuttgart 2006; A.M. Gomez, the legend of the lughing philosopher and its presence in Spanish literature (1500-1700), Cordoba 1984; T. Rütten, Demokrit, Lachender Philosoph und sanguinscher Melancholiker, Leiden-New YorkKöln 1992; Juwenalis, Satyry, [w:] L. Winniczuk (oprac.), Trzej satyrycy rzymscy. Horacy, Persjusz, Juwenalis, Warszawa 1958, s. 181; C. Dickin, Lucian of Samosata: Four Philosophical Lives, [w:] „Aufstieg und Niedergang der römischen Welt. Teil 2: Principat”, t. 36/5, Berlin-New York 1992, s. 3405-3450. W kwestii śmiechu u Luciana Samosaty zob. H.G. Nesselrath, Keiserlicher Skeptizismus in platinischen Gewand: Lukians ,Hermotimos”, [w:] „Aufstieg und Niedergang der römischen Welt. Teil 2: Principat", t. 36/5, Berlin-New York 1992, s. 3451-3482. C.W. Weber, Die Biotschaft aus der Tonne, Frankfurt a. M.-Berlin 1990; M. Hossenfelder, Antike Glückslehren, Stuttgart 1996.

6 J. Sławiński, Słownik terminów literackich, red. J. Sławiński, Wrocław 1988, s. 457.

7 Zob. A.G. Bem, Teorya poezji polskiej z przykładami $w$ zarysie popularnym analityczno-dziejowym, Petersburg 1989, s. 15; F. Pruchnicki, Lwów 1920, s. 82; H. Galle, Stylistyka i teorya literatury, Warszawa 1915, s. 4; B. Tomaszewski, Poetyka, Poznań 1935, s. 18; H. Cegielski, Nauka poezji, Poznań 1879, s. 115; S. Skwarczyńska, O pojęciu literatury stosowanej, [w:] „Szkice i felietony,, [w:] „Rocznik Literacki” Warszawa 1937-1938; M. Promiński, Gorzkie migdały poezji, [w:] „Kurier Literacko-Naukowy” 1936, nr 28; M.R. Mayenowa, Poetyka opisowa, Warszawa 1949, s. 13; K. Brodziński, Pisma estetyczno-krytyczne, Wrocław 1964, s. 32.

${ }^{8}$ Według Ignacego Chrzanowskiego: „trzy główne pierwiastki składają się na satyrę: dydaktyczny - pod postacią moralizacyj, liryczny - pod postacią uczucia autora, epiczny, który się objawia już to jako opowiadanie o jakiemś zdarzeniu, już to jako obrazowa i żywa charakterystyka danej postaci. Od sposobu wykonania każdej z tych rzeczy, części składowych satyry oraz wzajemnego ich stosunku zależy jej wartość artystyczna. Kiedy moralizacja jest sucha, uczucia wypowiedziane słabo lub nieszczerze, a opowiadanie bez plastyki i życia, wówczas satyra nie ma wartości, niewiele posiada i wtedy, gdy pierwszy pierwiastek dusi dwa drugie, wówczas bowiem satyra przestaje być poezyją i staje się prozą dydaktyczną."

9 W przedwojennym słowniku M. Artcta: satyra to ,utwór prozą lub wierszem potępiający, wyszydzający lub z lekka ośmieszający przywary, wady i nałogi ludzkie. To wyszydzanie wszelkiej śmieszności z humorem i dowcipem”, M. Arct, Słownik wyrazów obcych, Warszawa 1938. Późniejsze słowniki i encyklopedie przytaczają zbliżone definicje tego pojęcia. W myśl Słownika wyrazów 
prac poświęconych temu zagadnieniu Tomasz Stępień zauważa, że w dzisiejszych czasach satyra to zarówno utwory literackie, jak i anonimowe wierszowane hasła na murach, bądź programy rozrywkowe $\mathrm{w}$ radiu $\mathrm{i} w$ telewizji ${ }^{10}$. Nie dostrzega on jednak karykatury jako formy satyry. Nośnikiem satyry bywają różnego rodzaju przedstawienia, zwłaszcza programy kabaretowe. Treści satyryczne podawane są z ust do ust podczas różnego typu spotkań towarzyskich, bywają rozsyłane za pośrednictwem Internetu. Zbiory ich pojawiają się w książkach. Przekazy tego typu znajdziemy także na łamach dzienników i czasopism oraz z formie graffiti na murach miast i osiedli. Od satyry nie wolne są nawet reklamy, a umiejętne posługiwanie się nią zwiększa atrakcyjność takich wypowiedzi ${ }^{11}$.

obcych: „Satyra (łac. satira) to utwór literacki ośmieszający wady i przywary ludzkie, sposoby postępowania i poglądy, obyczajowość, stosunki polityczne i społeczne”, por. Słownik wyrazów obcych PWN, Warszawa, 1978. Niemal identycznie definiuje satyrę Słownik języka polskiego, pod red. M. Szymczak, T. III, Warszawa 1989, s. 182, a także Uniwersalny słownik języka polskiego pod red. S. Dubisza, T. III, Warszawa 2003. Z kolei Wielka Encyklopedia Powszechna: „satyra to utwór literacki będący wyrazem krytycznego stanowiska autora wobec rzeczywistości społecznej, ośmieszający lub nawet piętnujący przedstawione zjawiska, wady i przywary ludzkie, obyczajowość, stosunki socjalne, postawy i orientacje polityczne, sposoby postępowania i poglądy”, zob. Wielka Encyklopedia Powszechna, T. X, Warszawa 1967, s. 370. Identyczną definicję przynosi tom XXIV Wielkiej Encyklopedii Powszechnej PWN, Warszawa 2004. Niekiedy, nie definiując satyry, podkreśla się, że pojęcie to bywało różnie rozumiane w różnych okresach literackich. Zauważa się, że w okresie oświecenia termin ten „funkcjonował przede wszystkim jako nazwa gatunku literackiego, który obejmował utwory poetyckie prezentujące wyjaskrawiony obraz uznanych za szkodliwe zjawisk rzeczywistości społecznej (postaw politycznych, obyczajów, wad i przywar ludzkich) i realizujące przy tym utrwalone długą tradycją normy kompozycyjno-stylistyczne, a nawet wersyfikacyjne". Tak widzą satyrę polskiego Oświecenia M. Grzędzielska i T. Kostkiewiczowa. Por. Słownik literatury polskiego Oświecenia, wyd. II, Wrocław-Warszawa-Kraków 1996, s. 554, E. Wróblewska w odniesieniu do literatury polskiej XIX w. podkreśla jedynie, że satyra tego okresu przyjęła wiele wzorów wypracowanych w dobie oświecenia przez najwybitniejszych przedstawicieli tego gatunku. Jednak zatraciła właśnie w XIX w. charakter odrębnego gatunku literackiego, występując w różnych formach liryki, epiki czy dramatu, bądź jako element zasadniczy, bądź - poboczny. Zob. Słownik literatury polskiej XIX wieku, red. J. Bachusz, A. Kowalczykowa, Wrocław-Warszawa-Kraków 1997, s. 862-863. Zwykle wskazuje się, iż podstawy nowego, ponadgatunkowego rozumienia satyry zostały zawarte w rozprawie K. Brodzińskiego O satyrze, Warszawa 1822.

${ }^{10}$ T. Stępień, O satyrze, Katowice 1996, s. 7

${ }^{11}$ Utwory satyryczne pojawiały się w dziejach literatury polskiej zarówno w okresie staropolskim, jak i w dobie odrodzenia, w czasach saskich, oświecenia, kiedy to gatunki satyryczne rozwijały się szczególnie bujnie, a także w późniejszych okresach literackich. Jednak poważniejszych analiz doczekała się satyra tylko w niektórych z tych epok. Zob. I. Chrzanowski, Z dziejów satyry polskiej XVIII wieku, Warszawa 1909; A. Bereza, Problemy teorii stylizacji w satyrze, Wrocław 1966; P. Buchwald-Pelcowa, Satyra czasów saskich, Wrocław 1966, Z. Jastrzębski, Kpina i terror, „Teksty”1972, z. 3, Woźnikowski, Pamflet polityczny w czasach Stanisława Augusta, Wrocław 1973, J. Nowak-Dłużewski, Satyra polityczna Sejmu Czteroletniego, Warszawa 1933; tenże: Satyra polityczna konfederaci targowickiej i sejmu grodzieńskiego, Warszawa 1935; W. Floryan, Satyry Krasickiego a Boileau'a, [w:] „Księga referatów zjazdu naukowego im. I. Krasickiego, Warszawa 1936; D. Hopensztand, Satyry Krasickiego [w:] „Stylistyka teoretyczna w Polsce”, red. K. Budzyk, 
W teorii literatury podkreśla się, że satyra jest zjawiskiem ponadliterackim, interartystycznym i intersemiotycznym, funkcjonującym między szeroko rozumianą literatura, plastyką i formami audiowizualnymi (estrada, film, radio i telewizja). Operuje ona tylko dwoma podstawowymi sposobami kształtowania rzeczywistości. Pierwszy z nich polega na przedstawianiu rzeczywistości w „krzywym zwierciadle" na drodze selektywnej, wybiórczej rejestracji krytykowanych aspektów otaczającego świata. Takim ujęciem rzeczywistości operowały staropolskie utwory satyryczne, a współcześnie większa część felietonów, wierszy lub piosenek. Drugi sposób kształtowania rzeczywistości wykorzystywany przez satyrę stanowi groteska, będąca posuniętą do skrajności deformacją rzeczywistości, kontrastująca jakości estetyczne wywołujące poczucie absurdu istnienia ${ }^{12}$. Satyra miała spełniać wiele funkcji, wśród nich - dydaktyczną, polityczną - definiowaną częstokroć jako funkcję walki ${ }^{13}$. Zauważa się, że funkcja dydaktyczna satyry z biegiem czasu zaczęła ustępować ludycznej, co prowadziło do zatarcia granicy między satyrą, komizmem a humorem ${ }^{14}$. Niektórzy zastanawiają się nad sto-

Warszawa 1946, s. 54; A. Aleksandrowicz, Twórczość satyryczna Adama Naruszewicza, Warszawa 1964, J. T. Pokrzywniak, J. Goryczewski. Ttumacz, satyryk i krytyk; „, Satyra prawdę mówi” czyli rzecz o fatszywych przestankach, „Pamiętnik Literacki” 1984, z. 4, s. 57 M. Grzędzielska, T. Kostkiewiczowa, Satyra, [w:] „Słownik literatury polskiego Oświecenia”, red. T. Kostkiewiczowa, wyd. II, Wrocław - Warszawa - Kraków, 1996, s. 594 - 560; E. Wróblewska, Satyra polityczna Wielkiej Emigracji, Poznań 1977; także: Satyra, [w:] „Słownik literatury polskiej XIX wieku”, red. J. Bachórz, A. Kowalczykowa, Wrocław - Warszawa - Kraków 1991, s. 862-867; S. Frybes, W krainie groteski. Problemy satyry galicyjskiej drugiej połowy XIX w., Warszawa 1979; E. Warzynica-Zalewska, Pojęcie humoru, jego rola w powieściopisarstwie polskim drugiej połowy XIX w., „Przegląd Humanistyczny" 1992, nr 6, s. 82.

12 T. Stępień, O satyrze, s. 7 i n.

13 W kwestii funkcji dydaktycznej satyry por. uwagi Jana Lemańskiego w przedmowie do książkin J. Lemański, Satyra polska. Antologia, Warszawa 1958, s. 6. Na funkcję dydaktyczną zwraca uwagę zarówno Ignacy Krasicki pisząc: „I śmiech niekiedy moży być nauką”, jak i św. Augustyn zauważając: „miłość bliźniego nakazuje niekiedy śmiać się z błędów ludzi, aby ich samych skłonić do śmiania się z nich i unikania ich”, zob. S. Garczyński, Anatomia komizmu, Poznań 1989, s. 74-75.

14 T. Stępień, Zabawa, poetyka, polityka, Katowice 2002, s. 30. W kwestii komizmu zob. także K. Żygulski, Wspólnota śmiechu. Studium socjologiczne komizmu, Warszawa 1976; J.S. Bystroń, Komizm, wyd. 2, Warszawa 1960, passim; S. Szuman, O dowcipie i humorze, Warszawa 1936, s. 31. W literaturze podejmowano próby stworzenia teorii komizmu. Zob. w tym przedmiocie B. Dziemidok, O niektórych koncepcjach komizmu, „Annales UMCS”, vol. XIII, sectio F, Lublin 1961, s. 79-103; idem, O głównych formach komizmu, „Annales UMSC”, vol. XVI, sectio F, Lublin 1964, s. 57-61; idem, Społeczna rola komizmu, „Studia Socjologiczne” 1963, nr 4, s. 119-144; idem, The Comic and the Tragic. Certain Aspects of Mutual Relations, „Zagadnienia Rodzajów Literackich”, Łódź 1996, z. 2(3), s. 55-64; M. S. Tave, The Amiable Humorist. A Study in the Comic Theory and Criticism of the Eighteenth and Early Nineteenth Centuries, Chicago 1960; B. Zawadzki, Przeglad krytyczny ważniejszych teorii komizmu, „Przegląd Filozoficzny”, rocz. XXXII, 1929; E. Aubouin, Technique et psychologie du comique, Marseille 1948; E. Bergler, Laughter and the sense of humor, New York 1956; M. Eastman, Sense of Humor, New York 1922; H. Spencer, Fizjologia śmiechu, 
sunkiem satyry do komizmu, podkreślając że o przynależności jakiegoś utworu do satyry decydują nie jego formalno-gatunkowe cechy, ale fakt agresywnego, bezkompromisowego dyskredytowania i ośmieszania w tym utworze zjawisk stanowiących jego przedmiot ${ }^{15}$. Podejmowane są też próby odpowiedzi na pytanie czym satyra różni się od humoru ${ }^{16}$. Nie sposób się jednak oprzeć wrażeniu, że wynikające $\mathrm{z}$ tych prób systematyki podziały mają charakter czysto spekulacyjnych rozważań i niewiele wnoszą do istoty zagadnienia.

Satyra ma wiele odmian. Wskazuje się wśród nich satyrę literacką - wymierzoną w konwencję i szablony twórczości pisarskiej, chętnie uciekającą się do parodii, trawestacji, pastiszu i persyflarzu, satyrę społeczno-obyczajową - atakującą konkretne zwyczaje, niedomogi życia społecznego, przesądy, mody i snobizmy, satyrę osobistą - ośmieszającą w sposób aluzyjny lub wprost osoby powszechnie znane na forum publicznym - pełniące funkcje publiczne. Ten ostatni typ satyry chętnie odwołuje się do formy paszkwilu. Najistotniejszą rolę zdaje się odgrywać jednak satyra polityczna, skierowana przeciwko postaciom i instytucjom życia politycznego. Warto zauważyć, że pojęcie satyry politycznej nie zostało w literaturze zdefiniowane. Można natomiast zaryzykować stwierdzenie, że satyrą polityczną są wszelkie utwory (zwłaszcza literackie - w tym wiersze, piosenki, ske-

[w:] „Szkice filozoficzne” cz. 2, Warszawa 1983; J. Trzynadlowski, Komizm, [w:] „Studia literackie", Wrocław 1955, s. 75-94 A. Schopenhauer, Die Welt als Will und Vorstelung, t. 2, München 1911; F. Vischer, Aesthetik oder Wissenschaft das Schönen, t. 1, Lepizig 1846; D. Buttler, Komizm, dowcip i teoria dowcipu językowego, „Przegląd Humanistyczny” 1965, nr 1 (46), s. 35-65.

15 Stanowisko takie prezentuje Bogdan Dziemidok, wyodrębniając komizm prosty (farsowo-wodewilowy) oraz komizm złożony, który dzieli na humorystyczny i niehumorystyczny. Satyrę jako przekaz zaangażowany społecznie, zwalczający zło z punktu widzenia określonych ideałów zalicza on do komizmu niehumorystycznego, czyli dezaprobującego. Jego zdaniem na miano „satyrycznego" zasługuje utwór, którym dominuje dążenie do agresywnego i bezkompromisowego dyskredytowania i ośmieszania. Utwory, w których takie elementy jedynie się ujawniają (ale nie dominują), nie są satyrą, a mogą mieć co najwyżej satyryczne zabarwienie. Zob. B. Dziemidok, O komizmie, Warszawa 1967, s. 92-94.

${ }^{16}$ Zob. H. Sawecka, Humor i satyra, [w:] M. Abramowicz, D. Bertrand, T. Strużyński (red.), „Humor europejski”, Lublin 1994, s. 24. Według tej autorki, satyra ma wywoływać pogardę dla złych i bezmyślnych, ulepszyć świat, przyjmując moralność jako probierz rzeczywistości. Ma charakteryzować się postawą krytyczną, nieugiętością, agresywnością, tropić słabości, ma uciekać się do porównań, operując parodią i karykaturą. Adresowana jest do osób skłonnych do krytykowania. Natomiast humor powinien wzbudzać zrozumienie i współczucie dla dziwacznych aspektów świata, winien być zdystansowany, przychylny, tolerancyjny i wyrozumiały, oparty na realistycznej obserwacji, preferujący opowiadania w pierwszej osobie, chętnie posługujący się dialektami i językami zawodowymi. Por. także w przedmiocie poczucia humoru w Rzeczpospolitej szlacheckiej J. Porazinski, Staropolska kultura śmiechu. Ludzie-teksty-konteksty, Torun 2015, s. 23-56. Por. także B. Sułkowski, Zabawa. Studium socjologiczne, Warszawa 1984, s. 203 i n.; J. Grad, Problem karnawalizacji kultury współczesnej, [w:] J. Grad, H. Mamzer (red.), „Ludyczny wymiar kultury”, Poznań 2014, s. 9-20. 
cze, parodie, monologi, felietony, tzw. „,kawały”; plastyczne - zwłaszcza rysunki, karykatury, fotomontaże; filmy, programy radiowe i telewizyjne), które w całości lub we fragmentach ośmieszają, wyszydzają, piętnują działalność władz państwowych, ich przedsięwzięcia, cele, formy działalności, zadania i metody realizacji tych zadań, a także wyszydzające konkretne osoby biorące czynny udział w życiu politycznym. Satyra polityczna w wielu przypadkach tożsama z satyrą osobistą ${ }^{17}$. Jakkolwiek satyryczne utwory o charakterze politycznym chętnie są czytane, oglądane, powtarzane z ust do ust, to jednak dość szybko ulegają zapomnieniu, bowiem po wielu latach niezrozumiały staje się ich kontekst. Część politycznych przekazów o charakterze satyrycznym udało się ocalić dzięki rozmaitym zbiorom $\mathrm{i}$ antologiom albo $\mathrm{z}$ tej tylko racji, że zostały odnotowane na łamach pism satyrycznych. Wiele przepadło na zawsze w mrokach niepamięci. Niektóre zachowały się dzięki pamiętnikom i wspomnieniom ${ }^{18}$. Karykatury natomiast pozostały na

17 P. Buchwald-Pelcowa, Satyra, [w:] „Literatura polska. Przewodnik encyklopedyczny”, t. II, Warszawa 1985, s. 338 - 339

18 Wśród zbiorów takich wypada wspomnieć: Dowcip polityczny: Polska '93, Białystok 1993; Dowcip polityczny 1989-1992, Lublin 1992; Komuno wróć, Warszawa 1993; Na erewiańskiej fali, Warszawa 1990; Najnowszy dowcip polityczny, Lublin 1993, Nie chcem, ale muszem. 300 dowcipów o Lechu Wałęsie i nie tylko, Łódź 1992; Nowy dowcip polityczny, Warszawa 1997; Zielone pająki, Warszawa 1993; 501 dowcipów politycznych Wałbrzych 1993; Anegdota prawdę co powie..., J. Mikołajczak, B. Paluszkiewicz, M. Frajtak (wybór i oprac.), Poznań 1995; Antologia satyry polskiej 1944 - 1955, A. Marianowicz (red.), Warszawa 1955; A. Binkot, P. Binkot, W. Cesarski, Mate vademecum Peerelu $z$ wycinków gazet podziemnych w formie kalendarza robotniczego na rok 1990, wstęp S. Bratkowski, Warszawa, 1990; Z. Bosacki, Pierwszy lepszy Sejm. Stenogramy nie-parlamentarne, Poznań 1993; Dowcip surowo wzbroniony. Antologia polskiego dowcipu politycznego; V. Syguła-Gregowicz, M. Waloch (red.), Torun 1990; Dowcip surowo wzbroniony. Antologia polskiego dowcipu politycznego, t. II, V. Syguła-Gregowicz, M. Waloch (red.), Torun 1991; Kawat polski, M. Radecka, Warszawa 1983; Satyra polska w walce o pokój (wstęp J. Szeląg), Warzszawa 1950; Satyra prawdę mówi... 1928-1939, Z. Mitzner, L. Pasternak, Warszawa 1963; Żarty niepoświęcone (pozbierał i opowiedział ks. Jan Kracik), Kraków 1993; zob. także: J. Krzywda Pogorzelski, Pieśni $i$ wiersze satyryczne opozycji do rzadów legionowo-sanacyjnych 1926 - 1939, Detroid, 1981; T. Szczerbakowski, O grach językowych w tekstach polskiego i rosyjskiego kabaretu lat osiemdziesiatych, Kraków 1994; J. Fedorowcz, Felietony i dialogi, Warszawa 1989; J. Pietrzak, Co jest grane panie Janku, Warszawa 1992; S. Latanowicz, Satyra i polemika prasowa z przed stu laty, Poznań 1931; M. Tobera, Wesole gazetki. Prasa satyryczno-humorystyczna w Królestwie Polskim w latach 1905-1914, Warszawa - Łódź 1988; E. Skorupa, Lwowska satyra polityczna, Kraków 1992; W. Filler, Szczutek, Cyrulik Sewilski, Szpilki, Warszawa 1995; A Zakrzewski, Prosto z Wiejskiej, Wrocław - Warszawa - Kraków 1990; Z dziejów cnoty. Szpilki 1935-1985, Warszawa 1985; M. Raczkowski, Historyjki obrazkowe, Kraków 2004; Kawaty, czyli anegdoty polityczne z PRL i nie tylko, Warszawa 2005; L. Straszewicz, Śmiech w kajdanach. Kawały warszawskie z czasów okupacji, Kraków 1946; E. Lipiński, J. Szeląg, Pożegnanie z Hitlerem, Warszawa 1946; M.R. Buczkowski, Warszawski dowcip w walce 1939 - 1944, Warszawa 1947; Proletariusze wszystkich krajów, przepraszam. Komuna $w$ dowcipie, Warszawa 1991; M. Rychlewski (oprac.), Absurdy PRLu. Antologia, Poznań 2006; M. Ogórek, Przewodnik po Polsce, Warszawa 1991; Diplomex. Noty i anegdoty polityczne, Warszawa 1977; S. Kobyliński, Jak dobrze mieć sąsiada, Warszawa 1974; idem, Domysty, Warsza- 
łamach prasy, zarówno w czasopismach satyrycznych, niejako specjalistycznych, jak i w prasie literackiej, a także społeczno-politycznej ${ }^{19}$.

Nie wdając się w problematykę historyczno-literacką, pomijając kuszące zagadnienia teoretyczno-literackie, pozostawiając na uboczu bliższą klasyfikację satyry, ciekawe kwestie odnoszące się do form wypowiedzi satyrycznych, należy zauważyć, że satyra polityczna - zarówno w przeszłości, jaki w chwili obecnej - narażała twórców utworów satyrycznych na odpowiedzialność, wiodąc ich jako oskarżonych w sprawach karnych lub pozwanych w postępowaniu cywilnym przed oblicze organu sprawiedliwości. Wielokrotnie osoby ugodzone ostrzem satyry pomijały drogę prawną, rozprawiając się z twórcami utworów przy użyciu siepaczy i płatnych zabójców. Musi dziwić fakt, że jak dotąd brak w literaturze dzieła, które w sposób pełny i całościowy prezentowałoby te zjawiska. Jednocześnie, od starożytności po dzień dzisiejszy, społeczeństwo gotowe było przyznawać satyrykom, twórcom żartów, pamfletów, paszkwili, kalamburów i dowcipów prawo do wykpiwania rozmaitych stron życia społecznego. $Z$ tej swoistej licencji w przeszłości korzystali błaźni. Warto przecież pamiętać, że dowcip polityczny nie jest bronią, do której przeciwko politykom ucieka się jedynie społeczeństwo. Ze środków tych korzystają także chętnie sami politycy, gdyż okazuje się, że jest to broń bardziej skuteczna niż „uczone” teoretyczne wywody ${ }^{20}$.

Zauważyć należy, że karykatura jawi się jako jedna z form satyry. W języku potocznym „karykatura” to przesadne, ośmieszające uwydatnienie i wyolbrzymienie charakterystycznych cech postaci, przedmiotów lub wydarzeń w sztukach plastycznych, głównie w rysunku i grafice, lecz także w utworze literackim ${ }^{21}$. Ry-

wa 1975; Nie tylko do śmiechu. Dowcipu z czasów Peerelu 1948-1989. Z wieloletniej kolekcji Bronisława Saludy, wybrał oraz rysunkami opatrzył S. Kobyliński, Warszawa 1991. Znakomitą teoretyczną analizę języka polskiej satyry politycznej z początku lat dwudziestych przynosi mało znana, a świetnie udokumentowana praca Ireny Kamińskiej-Szmaj, Judzi, zohydza, ze czci odziera. Język propagandy politycznej w prasie 1918 - 1923, Wrocław 1994. Na ulotność przekazu satyrycznego zwracał ostatnio uwagę A. Mogilnicki stwierdzając, że zapisywanie dowcipów i anegdot w chwili „gdy są aktualne jest niebezpieczne, a gdy mieni ich aktualność giną przeważnie w pyle zapomnienia. A szkoda, przyczyniłyby się nieraz w przyszłości do charakterystyki epoki i jej poszczególnych działaczy". A. Mogilnicki, Wspomnienia adwokata i sędziego, Warszawa 2016, s. 140.

19 O. Bergmann, Prawdziwa cnota krytyk się nie boi. Karykatura w czasopismach satyrycznych drugiej Rzeczypospolitej, Warszawa 2012, passim; zob. także W. Husarski, Karykatura w Polsce, Warszawa 1926; H. Górska, E. Lipiński, Z dziejów karykatury polskiej, Warszawa 1977; J. Lenica, A. Marianowicz, J. Szeląg, Polska karykatura polityczna, Kraków 1951; A. Garlicki, J. Kochanowski, Józef Pitsudski w karykaturze, Warszawa 1931.

${ }^{20}$ E. Lanowski, Nie igra się z humorem, Prasa polityczna i jej rysuneczki, [w:] „Humor europejski”, Lublin 1994, s. 27.

${ }^{21}$ M. Szymczak (red.), Stownik języka polskiego, t. I, Warszawa 1988, s. 893. W myśl Uniwersalnego stownika języka polskiego to także rysunek lub utwór przedstawiający kogoś lub coś w sposób przesadny lub ośmieszający. S. Dubisz (red.), Uniwersalny stownik języka polskiego, Warszawa 2003, s. 63. 
sunki satyryczne charakteryzują się dużą różnorodnością. W literaturze zwykło się dzielić karykaturę na anonimową - nieprzedstawiającą wizerunku konkretnych osób; spersonifikowaną - przedstawiającą konkretne i rozpoznawalne dla odbiorców postacie; sytuacyjną - przedstawiającą anonimowe lub powszechnie znane osoby w określonych sytuacjach; portretową - prezentującą bez sytuacyjnego kontekstu tylko wizerunki znanych postaci; spersonifikowaną pojedynczą - z jednym bohaterem i zbiorową - z kilkoma bohaterami; wreszcie tworzące pewną tematyczną całość historyjki obrazkowe ${ }^{22}$. Zauważa się, że trudno wytyczyć granice między syntezą plastyczną a karykaturą. Wskazuje się, że bywają karykatury złośliwe, agresywne i brutalne, ale także łagodne i dobrotliwe. Innymi regułami rządzi się karykaturowanie przeciwnika, innymi przywódcy własnego obozu $^{23}$.

Początków karykatury zwykło się szukać w sztuce starożytnego Egiptu, Grecji i Rzymu. Wspomnieć tutaj należy o niektórych rzeźbach egipskich, greckim malarstwie wazowym, malowidłach ściennych w Herkulanum i Pompei ${ }^{24}$. Dalszy rozwój karykatury następuje w średniowieczu. Pojawiają się karykatury w iluminacjach dzieł rękopiśmiennych, w rzeźbach kapiteli, w których anonimowi artyści ukazywali wizerunki diabłów, ilustrowali przywary grzesznego życia ludzkiego, a w przekazach malarskich zachowania ówczesnych elit, w tym także przedstawicieli stanu duchownego. Były to przekazy wyjątkowo trwałe z tej racji, że znacząca część została uwieczniona w kamiennych rzeźbach. W założeniu miały one nie tyle rozbawiać, co przestrzegać przed określonymi zachowaniami ${ }^{25}$. Począwszy od wieku piętnastego satyryczne przekazy ikonograficzne zaczęły tracić anonimowość. Wśród ich twórców zwykło się wymieniać Hieronima Boscha, Leonarda da Vinci, Tycjana, Michała Anioła, Hansa Holbeina, Piotra Bruegla Starszego. Oczywiście można mieć wątpliwości czy zamiarem ich było tworzenie karykatur w dzisiejszym rozumieniu tego terminu, czy też zmierzali do przerysowania pewnych cech portretowanych osób, dając w tym wyraz mniej lub bardziej zawoalowanej krytyki ${ }^{26}$.

22 O. Bergmann, Prawdziwa cnota..., s. 23.

${ }^{23}$ A. Garlicki, J. Kochanowski, Józef Piłsudzki w karykaturze, s. 5.

${ }^{24}$ Champfleury, Histoire de la caricature antique, wyd. 2, Hachette 2013; J.P. Gebe, La caricature et la parodie dans le monde romain antique des origines à Juvênal, De Boccard 1966, s. 408.

${ }^{25}$ G. Doizy, J.B. Lalaux, Et dieu créa le rire! Satires et caricatures de la Bible, Alternatives, 2006.

${ }^{26}$ W kwestii historii karykatury zob. m.in. H. Górska, E. Lipiński, Z dziejów karykatury polskiej, Warszawa 1977; T. Gryglewicz, Groteska w sztuce Polski XX wieku, Warszawa 1977; Z. Micner, L. Pasternak, Satyra prawdę mówi... 1918-1939, Warszawa 1963; E. Lipiński, Drzewo szpilkowe, Warszawa 1989; I. Witz, J. Zaruba, 50 lat karykatury polskiej, Warszawa 1961; J.F. Champfleury, Histoire général de la caricature, vol. 1-5, Paris 1865-80; E. Kreis, E.H. Gombrich, Caricature, London 1940; D.F. Klingender, Hogarth and English Caricature, London-New York 1945; W. Hoff- 
Wynalazek druku znacząco przyczynił się do rozwoju karykatury, a spory religijne doby reformacji spowodowały upowszechnienie jej wśród odbiorców, częstokroć niepiśmiennych. Karykaturami posługiwali się Luter i Melanchton ${ }^{27}$, wykorzystując prace takich artystów, jak Lucas Cranach Młodszy ${ }^{28}$, Hans Holbein ${ }^{29}$, Stimmer i Manuel Deutsch. Z drugiej strony ich przeciwnicy także chętnie sięgali po podobny oręż. Była więc karykatura wykorzystywana w działaniach propagandowych przez obie strony sporu religijnego ${ }^{30}$. Marcin Luter uznał wręcz, że wynalazek druku jest aktem opatrzności pomagający w ewangelizacji i katechizacji $^{31}$. Skutkiem wynalezienia druku była instytucjonalizacja cenzury. Wkrótce obiektem działań cenzorskich stały się nie tylko teksty, lecz także obrazy, a wśród nich karykatury ${ }^{32}$.

man, Die Karikatur von Leonardo bis Picasso, Wien 1950; J. Grand-Carteret, L'Histoire, la vie, les mours et la curiosité par l'Image, le Pamphlet et le document (1450-1900), 5 vol., 1927; B. Tillier, À la charge. La caricature dans tous ses états de 1789 à 2000, L'Amateur 2005; A. Duprat, Histoire de France par la caricature, Larousse 1999.

27 J. Burkhardt, Stulecie reformacji w Niemczech (1517-1617). Między rewolucja medialna a przełomem instytucjonalnym, Warszawa 2009, s. 94. Por. także W. Hardtwig, U. von Hutten, Zum Verhältnis vom Indyviduum, Stand und Nation und der Reformationszeit, [w:] W. Hardtwig, „Nationalismus und Bürgerkultur in Deutschland 1500-1914. Ausgewählte Aufsätze”, Göttingen 1994, s. 7-15. Por. też tamże, Vom Elitenbewußtsein zur Massenbewegung, s. 34-54.

${ }_{28}$ Zob. H. Schilling, Marcin Luter. Buntownik w czasach przełomu, Poznań 2017, s. 528 i n.

${ }_{29}$ Przykładem może być satyryczna karykatura na bałwochwalczy kult świętego Krzysztofa i kult obrazów w formie rysunku na marginesie książki Erazma z Rotterdamu Pochwała głupoty, Bazylea 1515.

30 J. Grosicki, Sztuka i polityka 1587-1668, Warszawa 1983, s. 13-14; S. Michalski, Protestanci a sztuka. Spór o obrazy w Europie nowożytnej, Warszawa 1989; G. Kucharczyk, Kryzys i destrukcja. Szkice o protestanckiej reformacji, Warszawa 2017.

${ }^{31}$ M. Nieć, Komunikowanie polityczne w spoleczeństwach przedmasowych, Warszawa 2011, s. 218. Zob. J. Plamper, Kult Stalina. Studium alchemii władzy, Warszawa 2014, rec. M. Mazur, s. 233, Repozytorium Cyfrowe Instytutów Naukowych; Z. Nowak, Literatura sowizdrzalska wobec reformacji, „Pamiętnik Literacki: czasopismo kwartalne poświęcone historii i krytyce literatury polskiej" 1965 , nr 56/3, s. 17-32.

${ }^{32}$ W kwestii cenzury zob. J.M. Renault, Censure et caricatures, Pat à Pan, 2006, s. 21; J.L. Curry, J.R. Dassin, Press Control Around the World, New York 1982; U. Eisenhardt, Die kaiserliche Aufsicht über Buchdruck Buchhandel und Presse im Heiligen Römischen Reich Deutcher Nation (1476-1806). Ein Beitrag zur Geschichte der Bücher-und Pressezensur, Karlsruhe 1970; P.F. Grendler, Printing and censorship, Cambridge 1988, s. 49-51. Por. także T. Goban-Klas, Powstanie i kres cenzury w Europie Zachodniej, [w:] J. Kostecki, A. Brodzka (red.), „Piśmiennictwo - systemy kontroli - obiegi alternatywne”, t. 1, „Z dziejów kultury czytelniczej w Polsce”, Warszawa 1992 nr 7; N.G. Hammond, Dzieje Grecji, Warszawa 1973; J. Hemels, Pressezensur im Reformationszeitalter (1475-1648), [w:] „Deutsche Kommunikationskontrolle des 15 bis 20 Jahrhunderts, hrsg von H.-D. Fischer”, München 1982; I. Ihnatowicz, Człowiek. Informacja. Społeczeństwo, Warszawa 1989; J. Keller, Zakaz i cenzura książek w Kościele, „Studia z Dziejów Kościoła Katolickiego”, II 1960; A. Kłosowska, Kontrola myśli i wolność symboliczna, [w:] „Piśmiennictwo - systemy kontroli - obiegi alternatywne”, [w:] J. Kostecki, A. Brodzka (red.), 
Instytucja kontroli przekazu znana była od czasów starożytnych, zresztą nie tylko w Rzymie. Kontrolą obejmowano początkowo wypowiedzi ustne, a potem rękopisy, następnie pisma i księgi drukowane, a w końcu z chwilą jej powstania także prasę $e^{33}$. Po wyjściu z katakumb Kościół bardzo szybko przejął w swoje ręce znaczącą część kontroli obiegu informacji ${ }^{34}$. Podobnie postępowały władze świe-

„Piśmiennictwo - systemy kontroli - obiegi alternatywne”, t. 1, „Z dziejów kultury czytelniczej w Polsce", Warszawa 1992 nr 7; J. W. Miller, Censorship and the Limits of Permissions, London 1972; J. Pirożyński, Z dziejów obiegu informacji w Europie XVI wieku. Nowiny z Polski w kolekcji Jana Jakuba Wicka w Zurychu z lat 1560-1587, „Zeszyty Naukowe Uniwersytetu Jagiellońskiego MCLIV, Prace Historyczne”, z. 115, Kraków 1995; G.H. Putnam, The Censorship of the Church of Rome and its Influence upon the Production and distribution of Literature, New York 1967 (ed. II). W kwestii tej zob. także A. Dróżdż, John Milton a wolność stowa, „Annales Academiae Paedagogicae Cracoviensis”, Folia 8, Studia Politologica I (2002), s. 19-33. Autor ten słusznie stwierdza, że traktat Miltona przeciwko cenzurze nie znalazł poparcia w Anglii, a jego hasła doczekały się realizacji dopiero dwadzieścia lat po śmierci autora. Wolność słowa była zjawiskiem rzadkim, istniała w Księstwie Siedmiogrodu i gwarantowała prawo swobody wyznaniowej luteranom, kalwinistom, katolikom i unitom. Odnośnie sytuacji w Polsce zob. J. Dużyk, $Z$ dziejów cenzury w Krakowie w wiekach XV-XVII, „Rocznik Biblioteki Polskiej Akademii Nauk w Krakowie”, R. II, 1956; P. Buchwald-Pelcowa, Cenzura $w$ dawnej Polsce. Między prasa drukarska a stosem, Warszawa 1997; J. Szczepaniec, Sejm wielki wobec zagadnień cenzury $i$ wolności słowa, [w:] „Antynomie Oświecenia, Acta Universitatis Wratislaviensis No 1368, Prace Literackie” XXXI, 1991; B. Szyndler, Dzieje cenzury w Polsce do 1918 roku, Kraków 1993.

${ }^{33}$ Cenzorzy (łac. censores) to urzędnicy rzymscy, wybierani od 443 r. p.n.e. przez comitia centuriata początkowo na pięć lat, potem od 433 r. p.n.e. na półtora roku. Każdorazowo powoływano dwóch cenzorów. Do ich obowiązków należało sporządzanie spisów obywateli i ich majątków oraz listy senatorów i ekwitów. Ponadto powierzono im nadzór nad moralnością publiczną i obyczajami (censura morum, cura morum). Cenzorzy wydawali także przepisy zakazujące przepychu w jadle, odzieży i ozdobach. Kary przez nich wyznaczane (nota censoria, ignominia) miały charakter dolegliwości dotykających sfery honorowej (pozbawienie godności senatora, wyłączenie z grona ekwitów). Pod dozorem cenzorów pozostawały także budowle publiczne, wodociągi, świątynie, teatry. Przejawem kontroli wolności słowa było skazanie na śmierć Sokratesa za głoszenie myśli nie akceptowanych przez władze i uznanych za niebezpieczne dla państwa. Z obawy przed karą za treść poglądów filozoficznych Anaksagoras i Protagoras musieli uchodzić ze starożytnych Aten. Dzieło Protagorasa o bogach zostało publicznie spalone, podobnie jak prace Epikura z Samos, zwolennika atomistycznej teorii Demokryta i rozprawy Diagorasa. Temu ostatniemu, a także Eurypidesowi z racji głoszonych poglądów wytoczono procesy o bezbożnictwo. Przez całą starożytność niszczono dzieła rękopiśmienne ze względów politycznych lub religijnych.

${ }^{34}$ Było to konsekwencją faktu, że w tym okresie właśnie spory religijne przykuwały uwagę społeczeństwa. O spaleniu ksiąg przez nawróconych przez św. Pawła Efezjan wspominają już Dzieje Apostolskie. Sobory, a później sami papieże, potępiali nieprawomyślne księgi, władze świeckie ścigały je i niszczyły. Cesarz Konstantyn polecił spalić potępione przez władze duchowne księgi ariańskie i nestoriańskie. W Kodeksie Teodozjusza Codex Theodosianus nakazano m.in. spalenie wszystkich pism żydowskich. W 446 r. papież Leon I dokonał „rekapitulacji” wszystkich wcześniejszych władz chrześcijańskich dotyczących cenzury. Cesarz Justynian, wykonując orzeczenie soboru w Konstantynopolu z 536 r., nakazał spopielić pisma Sewera z Antiochii. Lista podobnych przypadków jest długa. Znajduje się na niej spalenie pism Focjusza w 869 r., spalenie ksiąg Joachima z Fiore, Jana Szkota Eriugeny oraz zmuszenie Abelarda do spalenia traktatu o Świętej Trójcy 
ckie $^{35}$. W średniowieczu dominowały kryteria religijne w ocenie kwestionowanego dzieła, a głos decydujący należał do instytucji kościelnych ${ }^{36}$. Począwszy od 1494 r. sporządzano spisy ksiąg zakazanych, których czytać i rozpowszechniać nie było wolno ${ }^{37}$. W średniowieczu uprawnienia cenzorskie zostały przejęte, co najmniej w części, przez uniwersytety, a głównie przez ich fakultety teologiczne ${ }^{38}$. Kłopotliwość ścigania dzieł opublikowanych drukiem skłaniała do interwencji na etapie wcześniejszym, czyli w formie cenzury prewencyjnej, zapobiegawczej ${ }^{39}$.

w 1121 r., zniszczenie wszystkich jego pism na polecenie papieża Innocentego III w 1140 r., spalenie pism Orygenesa, manichejczyków. Zob. J. Sobczak, Prawo prasowe. Podręcznik akademicki, Warszawa 2000, s. 14-15; H. J. Schütz, Verbotene Bücher. Eine Geschichte der Zensur von Homer bis Henry Miller, München 1990, s. 30; J. Green, The Encyclopedia of Censorship, New York - Oxford - Sydney 1990, s. 54.

${ }^{35}$ Król francuski, Ludwik Święty, rozkazał zniszczyć księgi talmudyczne potępione przez papieża Innocentego IV, a król angielski Ryszard III prace Jana Wiklefa. Kościół katolicki palił pisma „kacerzy”, a Kalwin i inni przywódcy reformacji czynili podobnie z pismami katolickimi. Charakterystyczne dla starożytności i średniowiecza było to, że poddawano ocenie dzieła już gotowe. Niszczono prace nieprawomyślne i karano ich autorów.

${ }^{36}$ Pierwszymi cenzorami badającymi i oceniającymi teksty pod względem ich zgodności z wiarą i moralnością byli papieże oraz biskupi. Twórcy dzieł teologicznych zwracali się do nich o lekturę i ocenę ich dzieł. Tak uczynił w końcu IV w. św. Ambroży przedstawiając swoją pracę biskupowi Sabinowi z Piacenzy, a także św. Augustyn prezentując listy przeciwko pelagianom papieżowi Bonifacemu I. Zob. W. Szczepański, Nowy indeks ksiag zakazanych oraz jego uzasadnienie, dzieje i nowe prawo, Kraków 1903, s. 22.

${ }^{37}$ Zob. w tym przedmiocie J. Krukowski, Zagadnienie indeksu ksiag zakazanych $w$ świetle posoborowych dokumentów Stolicy Apostolskiej, „Prawo Kanoniczne” 1970, R. XIII, nr 1-2, s. $217-$ 227; A. Petroni, Indeks Ksiag zakazanych i jego rozciagłość, „Ateneum Kapłańskie” 1933, t. 32, 291-299.

${ }^{38}$ W 1230 r. rektor uniwersytetu w Paryżu wydał zarządzenie poddające kontroli pisarzy przepisujących rękopisy dla celów studium uniwersyteckiego. W 1275 r. władze tegoż uniwersytetu stanowiły, że żaden rękopis nie może być rozpowszechniany bez ich zgody. Przepisy te stanowiły wzór dla innych uczelni. W 1275 r. w Anglii wydano edykt dotyczący osób rozpowszechniających fałszywe nowiny, a w 1408 r. arcybiskup Canterbury Arundel wprowadził zasadę zakazująca czytania wszystkich książek, które nie zostały wcześniej zbadane i zaaprobowane przez uniwersytety w Oxfordzie lub Cambridge. Konstytucja ta została potwierdzona przez Parlament w $1414 \mathrm{r}$. N.J. Karolides, M. Bald, D.B. Sova, 100 zkazanych ksiażek. Historia cenzury dziet literatury światowej, Warszawa 2004, s. 38; F. Seaton Siebert, Freedom of the Press in England 1476-1776, Urbana 1965; H. Misztal, Cenzura uprzednia w ustawodawstwie Kościoła zachodniego do Soboru Trydenckiego, „Roczniki Teologiczno-Kanoniczne” 1974, t. 21, z. 5, s. 81-94.

${ }^{39}$ W 1479 r. papież Sykstus IV oficjalnie nadał prawa cenzorskie uniwersytetowi w Kolonii, a potem innym uczelniom niemieckim, wyposażając je w moc karania drukarzy publikujących dzieła heretyckie. W Niemczech cenzurę prewencyjną na terenach swojej jurysdykcji wprowadzili: najpierw biskup Würzburga (1482 r.), potem rada miasta Frankfurtu za namową arcybiskupa Moguncji w 1486 r. Przyjmuje się niezbyt ściśle w licznych opracowaniach, że był to pierwszy urząd kontroli publikacji, a przyczyną jego powstania było upowszechnienie druku i pojawianie się nowych tłumaczeń Biblii oraz licznych traktatów protestanckich. W 1485 r. kurfirst moguncki usiłował objąć kontrolą książki wystawiane na sprzedaż w czasie targów we Frankfurcie nad Menem. Już w 1496 r. ce- 
System nadzoru nad drukarzami, stworzony przez bulle papieskie, został utrwalony postanowieniami V Soboru Laterańskiego w $1515 \mathrm{r}$. W tym też roku papież Leon X, znany skądinąd jako hojny mecenas artystów, wydał polecenie palenia na stosie książek opublikowanych bez zgody władz kościelnych ${ }^{40}$. Instytucje cenzury tworzyły też władze świeckie ${ }^{41}$. Na polecenie papieża Pawła IV (1476-1559) Inkwizycja opublikowała w 1559 spis ksiąg zakazanych Index librorum prohibitorum - powszechnie obowiązujący, zawierał nazwiska autorów, których w ogóle nie wolno czytać, wykaz dzieł niedozwolonych innych autorów, wreszcie spis niedozwolonych ksiąg anonimowych. Nowa jego wersja opracowana na Soborze Trydenckim opublikowana została $\mathrm{w} 1564 \mathrm{r}^{42}$. Utworzona przez papieża Piusa V w 1571 r. Kongregacja Indeksu zajęła się sprawą aprobaty druku i ewentualna korektą treści książki ${ }^{43}$. W 1596 r. papież Klemens VIII głosił nowe, trzecie wydanie

sarz Maksymilian I usiłował objąć kontrolą rozpowszechnianie druków, tworząc urząd generalnego superintendenta do spraw ksiąg w Niemczech. Następny papież Innocenty VIII w wydanej 1 listopada 1487 r. bulli Contra impressores librorum reprobatorum wprowadził cenzurę prewencyjną wszystkich druków, powierzając jej sprawowanie biskupom. W bulli tej nakazano drukarzom, aby przedłożyli biskupom spis wszystkich ksiąg już wydrukowanych. Treść ta została powtórzona w wydanej przez papieża Aleksandra VI 1 czerwca 1501 r. bulli Inter nostrae sollicitudinis curas i wysłanej arcybiskupom: kolońskiemu, mogunckiemu, trewirskiemu i magdeburskiemu, którzy albo sami, albo przez swoich wikariuszy generalnych i oficjałów mieli czuwać nad jej wykonaniem. J. Sobczak, Prawo prasowe..., s. 16; A. Muc, Cenzura uprzednia w prawodawstwie kościelnym. Zarys problematyki, „Biblioteka Nostra. Śląski Kwartalnik Naukowy" 2013, nr 2, s. 38-49.

${ }^{40}$ Leon X w Konstytucji z 1515 r. Inter sollicitudines domagał się zwiększenia liczby cenzorów i badania każdego tekstu przez dwie osoby oraz zaostrzenia kar. Zadrukowanie dzieł zawierających poglądy sprzeczne z wiarą groziła ekskomunika, zniszczenie całego nakładu, kary pieniężne oraz pozbawienie prawa drukowania książek przez okres jednego roku. Nakaz spalenia ksiąg Marcina Lutra zawarł papież Leon X w obszernej bulli z 15 czerwca 1520 r. Exurge Domine zbijającej tezy Lutra i potępiającej jego naukę. W 1526 r., już po śmierci Leona X, Wydział Teologiczny Uniwersytetu w Paryżu uzyskał prawo cenzurowania wszystkich dzieł o treści religijnej. W dwa lata później, w podobnym duchu wypowiedział się w tej kwestii papież Hadrian VI. W 1543 r. kardynał Giovanni Pietro Caraffa, Generalny Inkwizytor, późniejszy papież Paweł IV, wydał dekret, w myśl którego nie wolno drukować książek bez pozwolenia Inkwizycji. H. Misztal, Cenzura uprzednia pism i druków w Kościele zachodnim. Studium historyczno-prawne, s. 35.

${ }^{41}$ Cenzurę prewencyjną w krajach Rzeszy wprowadził edykt cesarski z 8 maja $1521 \mathrm{r}$. W tym też roku pisma zostały potępione mandatem wydanym w Wormacji. Konstytucja Sejmu w Norymberdze z 1524 r. nałożyła na stany Rzeszy obowiązek nadzorowania drukarń działających w poszczególnych państwach Rzeszy. Na tym obszarze obowiązek prowadzenia cenzury prewencyjnej potwierdzały konstytucje Sejmu Rzeszy w Spirze z 1529 r. i w Augsburgu z 1530 r. oraz ustawa dotycząca porządku publicznego i spraw karnych Rzeszy z $1548 \mathrm{r}$.

${ }^{42}$ Sobór Trydencki w dokumentach 8 IV 1546 r. Decretum de editione et usu sacrorum librorum oraz 24 III 1564 r. De libris prohibitis regulae decem określił szczegółowo procedurę prowadzenia cenzury kościelnej.

43 Od 1559 r. do 1948 r. Stolica Apostolska ogłosiła aż 16 oficjalnych edycji indeksu ksiąg zakazanych. W dniu 14 czerwca 1966 r. Kongregacja Nauki Wiary pozbawiła indeks znaczenia dyscyplinarno-karnego, stwierdzając że zachowuje on swą wartość jako ostrzeżenie przed treściami 
indeksu wraz z instrukcją nakazującą drukarzom i księgarzom składanie przysięgi przed biskupem lub wyznaczonym inkwizytorem, że będą prowadzić działalność zgodnie z nakazami religii katolickiej i przestrzegać przepisów kościelnych ${ }^{44}$.

Kontrolę przekazu wprowadzali także zwolennicy reformacji ${ }^{45}$. W dobie reformacji stopniowo cenzura rozszczepiała się na kościelną i świecką ze względu na instytucje, które ją sprawowały, oraz z uwagi na ścigane treści. W niektórych państwach dość długo jednak można było obserwować współdziałanie, a nawet symbiozę tych dwóch czynników ${ }^{46}$. We Francji Franciszek I dekretem z 1521 r. zakazał drukowania i rozpowszechniania książek bez uprzedniej zgody wydziału teologicznego Sorbony. Ta jednak wkrótce straciła przyznany jej w ten sposób monopol na kontrole druków, gdyż uznano, że jej decyzje powinny być zatwierdzane przez burmistrza Paryża. W latach 30. XVI w. przy parlamencie paryskim powstała tzw. Izba Gorejąca mająca za zadanie tępienie herezji ${ }^{47}$. W 1623 r. za

szkodliwymi dla wiary i dobrych obyczajów. H. Misztal, Cenzura uprzednia..., s. 45; J. Sobczak, Prawo prasowe..., s. 17-18; A. Muc, Cenzura uprzednia w prawodawstwie kościelnym..., s. 40.

${ }_{44}$ Papież Pius V w brewe Romani pontificis providentia zwrócił się przeciwko paszkwilantom i publikującym paszkwile gazetom. Na konieczność poddawania gazet cenzurze zwrócono także uwagę w 1567 r. w konstytucji zjazdu okręgów Rzeszy w Erfurcie. Na sejmie Rzeszy w Spirze w 1570 r. zaostrzono nadzór nad drukarniami, nakazując zamknięcie wszystkich pokątnych zakładów typograficznych. Mogły one istnieć odtąd tylko w miastach Rzeszy i w miejscowościach, w których rezydowali książęta Rzeszy lub miały siedzibę uniwersytety. W myśl ustawy z 1577 r. urzędnicy cesarza mogli bezpośrednio ingerować w sprawy cenzury, jeżeli władze lokalne nie wykazywały w tym zakresie właściwej inicjatywy. Zob. J. Sobczak, Prawo prasowe..., s.18.

${ }^{45}$ W 1524 r., a potem w 1529 r., w części państw niemieckich wprowadzono cenzurę pism katolickich polemizujących z tezami Marcina Lutra. Ustanowiono także w tym okresie obowiązek uzyskiwania przywileju na prowadzenie drukarni.

${ }^{46} \mathrm{~W} 1533$ r. na uniwersytecie sorbońskim poważnie zastanawiano się nad sposobem zniszczenia wynalazku druku. W następnym roku król Francji Franciszek I polecił zamknąć wszystkie drukarnie, zakazując pod karą śmierci otwierania nowych. Ostatecznie zezwolono na funkcjonowanie dwunastu drukarni, które poddano ścisłej kontroli. W 1563 r. zabroniono w ogóle drukować bez zgody władz państwowych. W Anglii w 1525 r. król angielski Henryk VIII ustanowił urząd wielkiego inkwizytora, na który powołał kardynała Tomasza Wolseya, polecając mu zapobieganie rozpowszechniania literatury katolickiej, sprzecznej z założeniami kościoła anglikańskiego. Politykę tę kontynuowali następni monarchowie, aż do czasów Jakuba i Karola I. W 1586 r. w Anglii powstała tzw. Izba Gwiaździsta mająca sprawować kontrolę nad drukarniami i drukarzami, wyposażona w prawo ustalania regulaminów obowiązujących drukarzy i drukarnie oraz sądzenia przestępstw prasowych. Izba ta ustanowiła system, w którym druk stał się monopolem drukarzy królewskich. Pod wpływem poglądów Johna Miltona cenzura w Anglii stopniowo słabła, a następnie została zniesiona w 1695 r. Zob. W. Wacławczyk, Idea wolności słowa Johna Miltona, Toruń 2008, passim; J. Max Patrick, The Prose of John Milton, Doubleday, Inc., Garden City, New York 1967, s. 249. Odnośnie powołania i działalności Izby Gwiaździstej zob. J. Clare, „Art made tongue-tied by authority”. Elizabethan and Jacobean Dramatic Censorship, Manchester 1990, s. 16-17.

47 Było to efektem pojawienia się antyklerykalnych satyr oraz tzw. plakatów rozwieszanych począwszy od 1534 r. w Paryżu i innych miastach Francji. J. Baszkiewicz, Historia Francji, Wrocław-Warszawa-Kraków-Gdańsk, 1974, s. 239. 
panowania Ludwika XIII obowiązek cenzurowania książek powierzono urzędowi kanclerskiemu. Kontrola uniwersytetu w Sorbonie dotyczyć miała jedynie teologii $^{48}$. W wieku XVIII istnieją oficjalnie trzy instytucje cenzorskie, a mianowicie: parlament, urząd kanclerski i Sorbona. Jednak tylko władza państwowa wydaje zezwolenia na druk i dysponuje wyłączną cenzurą prewencyjną, której urząd nosił oficjalną nazwę Bureau de la Librairie. Na czele jego stał dyrektor mianowany przez Kanclerza bądź Strażnika Pieczęci (Garde des Sceaux) ${ }^{49}$. Podlegali mu wszyscy cenzorzy oraz inspektorzy odpowiedzialni za kontrolę zarządzeńn ${ }^{50}$. Osobny problem stanowiła kwestia ścigania książek wydanych nielegalnie bądź sprowadzanych potajemnie z zagranicy ${ }^{51}$.

Światowe dzieje karykatury doskonale ilustrują zmiany polityczne, jakich doświadcza cywilizacja europejska i amerykańska, dokumentując jednocześnie rozwój techniki malarskiej i rysunkowej ${ }^{52}$.

${ }^{48}$ Zob. w tym przedmiocie: H.D. MacPherson, Censorship under Louis XIV, New York 1929; H.-J. Martin, Livre, pouvoirs et Socie à Paris Au XVII' siècle, 1598-1701, Genève, Droz 1969, t. I, s. 460-466, t. II s. 764-768; D. Roche, La censure, la Police du livre, [w:] R. Chartier, H.-J. Martin (red.), „Histoire de l'édition française”, Paris 1990, t. II „Le livre triomphant 1660-1830”, s. 88109. Por. także K. Pokorna-Ignatowicz, Kościół w świecie mediów. Historia-dokumenty-dylematy, Kraków 2000, s. 17 i n.

${ }^{49} \mathrm{~W}$ kwestii funkcjonowania cenzury we Francji zob. J.-P. Belin, Le commerce des livres prohibita à Paris de 1750 à1769, Paris, Berlin 1913; F. Furet, La librairie du royaume de France, [w:] „Livre et societé dans la France Au XVIII" siècle, Paris 1965, s. 3-32; M. Cerf, La censure royale à la fin de XVIII ' siècle, „Communications” 1967, nr 9, s. 2-28; N. Hermann-Mascard, La censure des livres à Pris à la fin de l'Ancien Régime 1750-1789, Paris 1968; B. de Negroni, Lectures interdites: le travail des censures au XVIII siècle, 1723-1774, Paris 1995.

${ }^{50}$ Dyrektor cenzury dokonywał selekcji tematycznej książek do cenzurowania, czytał raporty, decydując o ostatecznych losach rękopisu. Liczba cenzorów stopniowo rosła. W 1789 r. było ich już 76. Wśród nich dominowali ludzie wykształceni, należący do elity intelektualnej. Zob. D. Roche, La censure, la Police du livre..., s. 92; P. Matyaszkiewicz, Cenzura we Francji doby Oświecenia, „Roczniki Humanistyczne” 2003, t. LI, z. 5, s. 8. Por. także w kwestii dekretów królewskich poświęconych systemowi drukarni H.-J. Martin, La librairie française en 1777-1778, „Dix-huitième siècle" 1979, nr 11, s. 87-112; tenże, A la veille de la Révolution: crise et réorganisation de la librairie, [w:] „Histoire de l'édition française”, s. 681-693; R. Darnton, The Business $f$ Enlightenment: A Publishing History of the Encyclopédie: 1775-1800, Cambridge 1979; idem, Un commerce des livres sous le manteau en Provence à la fin d l'Ancien Régime, „Revue française d'histoire du livre” 1975, nr 9, s. 5-31.

${ }^{51}$ M. Benitez, La face cachée des Lumières. Recherches sur les manuscrits philosophiques clandestins d el'Age classique, Oxford-Paris 1996; A. McKenna, La literature clandestine, [w:] „Dictionnaire européen de des Lumières”, s. 651-654; G. Dulac, Les manuscrits clandestins et la mouvement philosophique jusqu'en 1750, [w:] „Histoire littéraire de la France”, s. 163-174.

${ }^{52}$ L. Baridon, M. Guédron, L'Art et l'histoire de la caricature: Des origines à nos jours, Paris 2006; F. Bohne (red.), Der Deutsche in seiner Karikatur. Hundert Jahre Selbstkritik, Stuttgart 1963; B. Bornemann, La Caricature, Art et Manifeste du XVI siècle à nos jours, Genève 1974; H. Fischer; F. Vaßen (red.), Europäische Karikaturen im Vor- und Nachmärz, Bielefeld 2006. „Forum Vormärz Forschung”, Jahrbuch 11, 2005; E. Fuchs, Die Kari- 
Jest rzeczą ciekawą, że zwalczaniem karykatur zajęły się władze administracyjne właśnie we Francji. Liczne karykatury, a także paszkwile obyczajowe i polityczne, jakie w drugiej połowie XVIII w. pojawiły się we Francji ${ }^{53}$ wyraźnie nie dorównywały karykaturom włoskim ${ }^{54}$ oraz angielskim karykaturom tworzonym przez W. Hogartha i J. Gillray'a oraz T.H. Rowlandsona i G. Cruikshanka, znanego zwłaszcza z karykatur Napoleona Bonapartego, członków brytyjskiego rządu i rodziny królewskiej ${ }^{55}$. J. Baszkiewicz zwraca uwagę, że wielkie malarstwo hi-

katur der europäischen Völker. Bd. 1: Vom Altertum bis zur Neuzeit. Bd. 2: Vom Jahre 1848 bis zur Gegenwart, Berlin, 1901-1903; T. Knieper, Die politische Karikatur: Eine journalistische Darstellungsform und deren Produzenten, Köln 2002; J. Kotek, Au nom de l'antisionisme. L'image des juifs et d'Israel dans la caricature depuis la seconde Intifada, Brüssel-Paris 2004; Ch. Lamb, Drawn to Extremes: The Use and Abuse of Editorial Cartoons, New York 2004; T. Mosher, Drawn and Quartered, „Leader and Dreamers Commemorative Issue” 2004, s. 171; G. und I. Oesterle, Karikatur. In: Joachim Ritter; Karlfried Gründer: Historisches Wörterbuch der Philosophie [...], nr 4, Basel-Darmstadt 1980, s. 696-701; A.Platthaus, Das geht ins Auge. Die Geschichte der Karikatur, Berlin 2016; C. Rentmeister, Honoré Daumier und das Häßliche Geschlecht. Frauenbewegung in der Karikatur des 19. Jahrhunderts, [w:] „Honoré Daumier und die ungelösten Probleme der bürgerlichen Gesellschaft”, Berlin 1974; Stuttgart 1975; Graz 1977; F. Schneider, Die politische Karikatur, München 1988; F. Wendel, Das neunzehnte Jahrhundert in der Karikatur, Berlin 1925; F. Wendel, Das Schellengeläut. Kulturkritische Karikaturen des 19. Jahrhunderts, Berlin 1927; F. Wolf, Die Kunst der Karikatur, Bramsche 2008; Zibaldone Nr. 38, Karikaturen: Von Bernini bis Forattini, Tübingen 2004.

${ }^{53}$ Oglądający francuskie karykatury Wolfgang Goethe był zarówno poruszony przestępczością obrazu, jak i zniesmaczony wulgaryzmem. Pod wpływem przedstawionych karykatur rozpoczął pisanie traktatu poświęconego m.in. karykaturom, którego nigdy jednak nie dokończył. R. Reichardt, H. Kohle, Visualising the Revolution: Politics and the Pictorial Arts in Late Eighteenth Century France, London 2008, s. 7.

${ }^{54}$ We Włoszech wybitnymi karykaturzystami byli Annibale Carraci i Baccio di Banco, tworzący w wieku XVII, a później Giovanni Lorenzo Bernini, znany bardziej jako rzeźbiarz, architekt kierujący budową Bazyliki św. Piotra oraz kierownik budowy Palazzo Barberini w Rzymie, zob. A. Bochnak, Historia sztuki nowożytnej, Warszawa-Kraków 1985, t. 2, s. 30; M. Grazia Bernardini, Maurizio Fagiolo dell'Arco, Gian Lorenzo Bernini: regista del barocco, Venezia, Skira, 1999, F. Petrucci, Bernini pittore. Dal disegno al „maraviglioso composto”, Roma, Ugo Bozzi Editore s.r.1., 2007, L. Irving, Bernini and the Unity of the Visual Arts, New York 1980, P. Schneider, P. Zitzlsperger (red.), Bernini in Paris. Das Tagebuch des Paul Fréart de Chantelou über die Reise des Gianlorenzo Bernini nach Frankreich, Berlin 2006; Guercino (właśc. Giovanni Francesco Barbieri), zob. S. Zuffi, F. Castria, Malarstwo włoskie. Mistrzowie i arcydzieła, Warszawa 1998; J. Guze, J.Kilian, J. Sikorska, Guercino. Triumf baroku. Arcydzieła z Cento, Rzymu i kolekcji polskich, Warszawa 2013, oraz Pier Leone Ghezzi. Zaliczanie Guercino do karykaturzystów lansowane przez J.F. Champfleury'ego, Histoire générale..., wydaje się dyskusyjne. Karykatur dopatrzyć się można w jego rysunkach, których największa kolekcja zmagazynowana jest w Królewskiej Bibliotece Zamku Windsor w Wielkiej Brytanii.

${ }_{55}$ O karykaturach Williama Hogartha zob. R. Paulson, William Hogarth, Warszawa 1984; R. Paulson, Hogarth's Graphic Works, 3rd edn, London 1989; S. Rodary, William Hogarth, „Wielcy Malarze" nr 84, Warszawa 1999; M. Żuławski, Od Hogartha do Turnera, Warszawa 1973; E. Einberg, William Hogarth: A Complete Catalogue of the Paintings, New Haven and London 
storyczne Jacquesa-Louisa Davida nie wywierało szczególnego wpływu na masy, natomiast jego karykatury tak. Podkreśla on, że w czasach rewolucji i później publikowano zarówno luksusowe akwatinty i mezzotinty, jak i sprośne grawiury, tanie, kolorowane akwaforty, z reguły anonimowe, często wychodzące spod ręki znanych twórców, którzy z różnych przyczyn woleli ich nie podpisywać. Zainteresowanie karykaturą polityczną, jak wskazuje ten autor, było ogromne. „Groteskowy realizm” karykatur odpowiadał plebejskiej mentalności. Lud znał je z tradycji karnawałowej i plebejskiego spektaklu. Grawiury rewolucyjne dostępne były dla mało zasobnych, oglądano je zbiorowo, a wpływ ich na umysły i serca był duży. Karykatury te pełniły funkcję propagandową ${ }^{56}$.

Nie sposób w tym miejscu przedstawiać dzieje cenzury we Francji pod koniec wieku XVIII. Wspomnieć jedynie wypada, że w okresie rewolucji 1789 r. w art. 11 Deklaracji Praw Człowieka i Obywatela zniesiono nawet na czas jakiś cenzurę ${ }^{57}$, lecz z obawy przed utrwaleniem nastrojów rewolucyjnych dość szybko, bo dekretem z dnia 29 marca 1793 r., ją przywrócono ${ }^{58}$. Okres rządów Napoleona to budowa systemu cenzury jako instytucji państwowej. Zasadzał się on na nałożeniu na księgarzy obowiązku deponowania w prefekturze policji dwóch egzemplarzy książek, które miały być wprowadzone do obiegu wydawniczego. Powołano też wówczas Główną Dyrekcję Druku i Księgarń, podległą bezpośrednio ministrowi spraw wewnętrznych i spełniająca funkcję cenzury. Ograniczono liczbę drukarni, wprowadzając jednocześnie system inspektorów mających kontrolować przestrzeganie dekretów i zarządzeń cenzury. Ściśle kontrolowano import książek

2016; J.J. Eschenburg, Über William Hogarth und seine Erklärer, Till Kinzel (red.), Hannover 2013. O twórczości satyrycznej i karykaturach Jamesa Gillroy'a zob. D. Hill, Mr. Gillray: The Caricaturist, a Biography, Phaidon Publishers Incorporated, distributed by New York Graphic Society, 1965; I. Haywood, The Transformation of Caricature: A Reading of Gillray's The Liberty of the Subject, „Eighteenth-Century Studies” 2010, nr 43.2, s. 223-242; J. Gillray, The Satirical Etchings of James Gillray, Dover Publications 1976; Е. Некрасова, Очерки по истории английской карикатурь кониа 18 и начала 19 веков, Ленинград 1935; ,, Delights of Harmony”- James Gillray als Karikaturist der englischen Musikkultur um 1800, Wien/Köln/Weimar: Böhlau 2017. Twórczość Thomasa Rowlandsona analizują M. Payne, J. Payne, Regarding Thomas Rowlandson 1757-1827, His Life, Art \& Acquaintance, London 2010; R. R. Wark, Drawings by Thomas Rowlandson in the Huntington Collection, San Marino, CA 1975. F. G. Stephens, A memoir of George Cruikshank, Londres 1891; R.L Patten, George Cruikshank's life, times, and art, Londyn 1992.

56 J. Baszkiewicz, Nowy człowiek, nowy naród, nowy świat. Mitologia i rzeczywistość rewolucji francuskiej, Warszawa 1993, s. 174-176.

${ }^{57}$ Odnośnie prawa prywatnego w czasach rewolucji zob. M. Garaud, Histoire générale du droit privé français de 1789-1804, t. I: La Révolution et l'égalité civile, Paris 1953, t. II: La Révolution et propriété, Paris 1959.

${ }_{58}$ P. Matyaszewski, Cenzura we Francji doby Oświecenia, s. 5-23; L. Andries, Les imprimeurs libraires parisiens et la liberté de la presse (1789-1795), „Dix-huitième siècle” 1989, nr 21, s. 247261; Ch. Walton, Policing Public Opinion in the French Revolution: The Culture of Calumny and the Problem of Free Speech, Oxford 2009. 
z zagranicy ${ }^{59}$. W okresie stu dni Napoleona, cenzura została zniesiona, a akt ten został potwierdzony 20 lipca 1815 r. przez Ludwika XVIII ${ }^{60}$.

Działalność francuskich organów cenzury dotyczyła także karykatury i przedstawień teatralnych. Objęte nią był również czasopisma satyryczne ${ }^{61}$. Zakazano publikacji wielu tysięcy karykatur, a pewna liczba ich twórców oraz wydawców znalazła się w więzieniu. Do odpowiedzialności pociągnięto także kolporterów i dystrybutorów ${ }^{62}$. Cenzura karykatury była znacznie trudniejsza niż kontrola dzieł sztuki, która odbywała się zresztą zakulisowo ${ }^{63}$. W literaturze konstatuje się, że karykatury były przedmiotem szczególnie ostrych restrykcji z uwagi na ich łatwą dostępność, masowość oraz to, iż ich adresatami byli przedstawiciele klas niższych i mniej wykształconych ${ }^{64}$.

Konstytucja z 1830 r. formalnie deklarowała wolność wypowiedzi. Zniesieniu cenzury i zmianie prawa prasowego po $1830 \mathrm{r}$. towarzyszyło jednak zaostrzenie odpowiedzialności za obrazę króla ${ }^{65}$. Dzięki temu właśnie w początkach lat trzydziestych nastąpił rozkwit karykatury i satyry, a liczne procesy wytaczane ich twórcom miały olbrzymi wpływ na wykształcanie się idei wolności sztuki ${ }^{66}$. Wytaczane karykaturzystom sprawy dotyczyły karykatur króla. Szczególnie ważne były procesy karykaturzysty i wydawcy czasopisma satyrycznego Charlesa Philipona oraz rysownika Honoré Daumiera ${ }^{67}$. Skazanie obu twórców nie przyniosło

${ }^{59} \mathrm{~B}$. Vouillot, La Révolution et l'Empire: un nouvelle réglementation, [w:] R. Chartier, H.-J. Martin (red.), „Histoire de l'édition française”, T. II, „Le Livre triomphant (1660-1830)”, Paris 1990, s. 694-708.

${ }^{60}$ I. de Conihout, La Restauration: contrze et liberté, [w:] R. Chartier, H.-J. Martin (red.), „Histoire de l'édition française”, T. II, „Le Livre triomphant (1660-1830)”, Paris 1990, s. 709-717.

${ }^{61}$ R. J. Goldstein, Censorship of Caricature and the Theatre in Nineteenth-Century France: An overwiev, „Yale French Studies” 2012, nr 122 „Out of Sight: Political Censorship of the Visual Arts in Nineteenth-Century France", s. 14-36.

${ }^{62}$ D. O'Brien, Censorship of Visual Culture in France 1815-1852, „Yale French Studies” 2012, nr 122 „Out of Sight: Political Censorship of the Visual Arts in Nineteenth-Century France”, s. 43.

${ }^{63}$ W okresie Restauracji z muzeów i państwowych galerii usunięto wówczas prace Jacquesa-Louisa Davida, Antonine-Jean Grosa, Anne-Louis Girodet, Francoisa Gerarda gloryfikujących Napoleona i jego zwycięstwa. D. O'Brien, Censorship of Visual Culture ..., s. 46.

${ }^{64}$ R. J. Goldstein, Censorship of Caricature ..., 25; D. O'Brien, Censorship of Visual Culture..., s. 40.

${ }^{65}$ O. Watts, Daumier and Replacing the King's Body, [w:] A. Wagner, R. Sherwin (red.), „Law, Culture and Visual Arts", New York-London 2014, s. 430.

${ }^{66}$ D.S. Kerr, Caricature and French Political Culture1930-1848: Charles Philipon and the Illustrated Press, Claredon Press 2000; R. Terdiman, The Theory and Practice of Symbolic Resistance in Nineteenth-century France, Cornell University Press 1989.

${ }^{67} \mathrm{~W}$ pierwszym przypadku chodziło o czterofazowy proces przemieniania oblicza króla w gruszkę, w drugim o przedstawienie króla jako żarłocznego Gargantuę połykającego wszelkie dobra dostarczane przez lud. Zob. w tym przedmiocie E. Childs, The Body Impolitic: Press Censorship and the Caricature of Honore Daumier, [w:] D. De la Motte, J.M. Przybylski (red.), „Making the 
spodziewanego przez władze efektu. Karykatura autorstwa Philipona powielana była w tysiącach egzemplarzy, prezentowana w rozmaitych miejscach i konfiguracjach, publikowana $\mathrm{w}$ postaci afiszy, drukowana w prasie.

Efektem tej sytuacji było złożenie przez rząd królowi propozycji ponownego ustanowienia systemu cenzury. Minister sprawiedliwości Jean-Charles Persil w sporządzonej opinii prawnej w kwestii możliwości ograniczenia swobody publikacji druków rysunkowych wyraził pogląd, że gwarancja prawa do publikacji ogranicza się do swobodnego manifestowania opinii, które mogą być wyrażone jedynie w słowie, gdyż są adresowane do umysłów odbiorców, natomiast nie obejmuje ona manifestacji poglądów przybierających postać działania, a więc rysunków, które powstają dopiero wówczas, gdy opinie zmieniają się w czyny. W efekcie zakaz cenzury nie dotyczy rysunków. Tym samym w opinii dokonano rozróżnienia wolności słowa i wolności ekspresji, uznając że ta ostatnia jest bardziej niebezpieczna, gdyż jest skierowana do większej rzeszy odbiorców odwołuje się do emocji i może być odczytana jako wezwanie do politycznego oporu wobec władzy królewskiej ${ }^{68}$. Opinia Persila stała się podstawą przygotowania tzw. prawa wrześniowego, które weszło w życie w 1835 r., ustanawiającego cenzurę karykatury i przedstawień teatralnych. Ograniczało ono jednak działania cenzorskie do jednorazowego działania i zezwolenie na publikacje karykatury bądź przedstawienie nie pozwalało już na późniejszą zmianę decyzji ${ }^{69}$. Takie rozwiązanie prowadziło jednak do tego, że cenzor znacznie chętniej odmawiał wyrażenia zgody na publikację karykatury. Po wprowadzeniu tej regulacji karykaturzyści nadal byli skazywani za publikowanie swoich prac, ale z surowszą sankcją spotykali się wydawcy. Po objęciu funkcji Ministra Spraw Wewnętrznych przez Victora duca de Persigny ${ }^{70}$ wprowadzono nowe reguły kontroli wydawnictw prasowych, do których stosować się miały wszystkie urzędy cenzorskie. Celem ich było zniechęcenie karykaturzystów do tworzenia, a wydawców do publikowania kontrowersyjnych ilustracji. Innym rozwiązaniem było wprowadzenie obowiązku wpłacenia kaucji przez prasę o charakterze politycznym. Żądane kwoty były stosunkowo wysokie i, jak deklarowano, przeznaczone być miały na pokrycie ewentualnych kar grzywny wymierzonych za publikowanie niedozwolonych obrazów.

\footnotetext{
News: Modernity and the Mass Media in Nineteenth-Century France", University of Massachusetts Press 1999, s. 51; M. Hanoosh, Baudelaire and Caricature: From the Comic to an Art of Modernity, Penn State Press 1992, s. 118; O. Watts, Daumier and Replacing the King's Body..., s. 431.

${ }^{68}$ R. J. Goldstein, Censorship of Political Caricature in Nineteenth-Century France, Kent State Univeristy Press 1989, s. 2.

${ }^{69}$ E. Childs, The Body Impolitic..., s. 62.

70 J. G. V. Fialin de Persigny, H. de Laire d'Espagny, Mémoires du duc de Persigny, Paris 1896; J. G. V. Fialin de Persigny, H. de Laire d' Espagny, Le duc de Persigny et les doctrines de l'empire, Paris 1865 .
} 
Po wejściu w życie stosunkowo liberalnej ustawy o prawie prasowym zniesiono konieczność składania kaucji, uznano jednak za konieczne przedkładanie policji przeznaczonych do publikacji materiałów prasowych. Wyznaczono jednak bardzo długi, bo piętnastodniowy termin na podjęcie przez stosowne organy decyzji o możliwości publikacji. Zwrócić w tym miejscu wypada uwagę, że w prawie tym przewidziano ochronę prywatności, której naruszenie, ścigane z oskarżenia prywatnego, było zagrożone grzywną 500 liwrów ${ }^{71}$. Generalnie w okresie drugiego Cesarstwa Francuskiego do roku 1870 cenzura opierała swoje działania na dekrecie organicznym z 17 lutego 1852 r., w myśl którego żaden rysunek, litografia, medalion, druk, emblemat nie mógł być publikowany, wystawiany lub sprzedany bez wcześniejszej autoryzacji przez urząd policji miasta Paryża lub prefekturę odpowiednich departamentów. W przypadku naruszenia tych przepisów groziła konfiskata wspomnianych przedmiotów przez sądy korekcyjne oraz kara więzienia od jednego miesiąca do roku i grzywna W wysokości od 100 do 1000 franków $^{72}$.

Nowy minister sprawiedliwości Émile Olivier, adwokat i historyk, twórca nowego liberalnego rządu, 26 stycznia 1870 r. przedstawił nowe prawo prasowe, w którym ocena naruszenia prawa autorskiego pozostawiona została biegłym ${ }^{73}$. Wkrótce po przegranej wojnie z Prusami i abdykacji Napoleona III dekretem z 10 września 1870 r. proklamowano wolność prasy. Organy cenzorskie działały jednak nadal wbrew prawu, a w okresie Komuny Paryskiej od marca do maja 1871 r. cenzura została nawet zaostrzona. Po tych wypadkach wojskowy administrator Paryża generał Paul de Ladmirault ${ }^{74}$ dekretem z dnia 28 grudnia 1871 r. zakazał dystrybucji jakichkolwiek przedstawień Komuny, z wyjątkiem obrazów ruin Paryża. Obowiązywanie tego dekretu aktem z dnia 25 listopada 1872 rozszerzono na całą Francję. Treści wspomnianego aktu normatywnego wskazano, że zabronione jest wystawianie, sprzedaż jakiegokolwiek rysunku, fotografii lub emblematu, który mógłby prowadzić do naruszenia spokoju społecznego, zwłasz-

71 J. Wechsler, Daumier and Censorship, „Yale French Studies” 2012, nr 122 „Out of Sight: Political Censorship of the Visual Arts in Nineteenth-Century France", s. 55-75.

${ }^{72}$ B. Tillier, D. Nicholson-Smith, The Impact of Censorship on Painting and Sculpture, „Yale French Studies” 2012, nr 122 „Out of Sight: Political Censorship of the Visual Arts in Nineteenth-Century France", s. 81.

${ }^{73}$ D. W. Houston, Émile Ollivier and the Hohenzollern Candidacy, „French Historical Studies” 1965, nr 4\#2, s. 125-49. Co ciekawe, É. Olivier był obiektem działań licznych karykaturzystów przedstawiających go jako człowieka siedzącego na kanapie z dwoma ministerialnymi tekami lub pojedynkującego się jednocześnie z Napoleonem III i opozycją. Nie były to jednak karykatury tak napastliwe jak te, które malował Honoré Daumier portretując przemianę króla.

${ }^{74}$ M. Gallet-Villechange, Le général Paul de Ladmirault, un enfant du Poitou sous les aigles impériales, Anovi 2008. 
cza portretów osób oskarżonych bądź skazanych za udział w aktualnych wydarzeniach insurekcyjnych ${ }^{75}$.

W okresie dość liberalnej III Republiki ustawą z dnia 28 lipca 1881 r. zadeklarowano wolność prasy. Tak więc zauważyć należy, że mimo obowiązywania konstytucji z 1830 r. działała sprzeczna z deklaracją konstytucyjną cenzura, która formalnie niby nie istniała. Dopiero przyjęcie w $1881 \mathrm{r}$. liberalnego prawa prasowego zniosło restrykcje prawne rozproszone w licznych aktach prawa i w rozmaitych przepisach. W praktyce wolność przekazu była jednak nadal ograniczana, najpierw prawem z dnia 2 sierpnia 1882 r., w którym przewidziano odpowiedzialność za naruszenie dobrych obyczajów, potem 16 marca 1893 r., starając się chronić obce głowy państw oraz przedstawicieli dyplomatycznych, wreszcie aktami normatywnymi z dnia 2 grudnia 1893 r. i 28 lipca 1894 r., mającymi powstrzymać anarchistyczną propagandę i prawem z dnia 3 grudnia 1889 r., którego celem było przeciwdziałanie naruszeniom praw jednostek. Wspomniane akty normatywne dawały możność ingerencji także w teksty satyryczne i karykatury ${ }^{76}$.

Karykatura była zarówno w dobie oświecenia u schyłku wieku XVIII, jak i do lat 80 . XIX w. orężem używanym w walkach politycznych, społecznych i gospodarczych, a także w toku osobistych rozgrywek, o różnym zresztą charakterze. Rolę tę, jak się wydaje, pełni do dziś, przy czym w obecnej dobie jej przejawem są częstokroć złośliwe tzw. memy. Mimo restrykcji prawnych i gorsetu przepisów udało się jej przetrwać, chociaż twórcy i wydawcy karykatur częstokroć podlegali dość surowym karom. Warto zauważyć, że charakterystycznym dla Francji zjawiskiem była nie tylko instytucjonalizacja cenzury, ale istnienie jej organów, mimo formalnych, konstytucyjnych deklaracji o wolności słowa.

\section{POLITICAL CENSORSHIP AND CARICATURE. FRENCH EXPERIENCES FROM SECOND HALF OF THE $18^{\text {TH }}$ CENTURY AND FROM THE FIRST HALF OF THE $19^{\mathrm{TH}}$ CENTURY. A CONTRIBUTION TO THE FIGHT FOR FREEDOM OF SPEECH}

\section{Summary}

Caricature is one of the forms of artistic expression and it has a similar role to satire. Consequently, some people consider caricature to be one of the forms of satire. Caricature has its origins in ancient times. The history of caricature is illustrated by political changes that civilization experienced. The administrative authorities attempted to fight caricature in numerous countries and France was one of them. This process is a part of the history of censorship that began in Roman times. Afterwards, it developed further during the

\footnotetext{
${ }^{75}$ B. Tillier, D. Nicholson-Smith, The Impact of Censorship ..., s. 81.

${ }^{76}$ Ibidem.
} 
Christian period of the Middle Ages until the $19^{\text {th }}$ century. Unfortunately, this procedure is present in certain areas even today. The most interesting solutions were the ones adopted in France. Moreover, it is worth noting that the phenomenon of institutionalization of censorship was not the only characteristic element in France. There were also censorship bodies present in the country despite the formal constitutional declarations of freedom of speech.

\section{CENSURE POLITIQUE DE LA CARICATURE. EXPÉRIENCE FRANÇAISE DE LA SECONDE MOITIÉ DU XVIII ${ }^{\mathrm{E}}$ SIĖCLE ET DE LA PREMIÈRE MOITIÉ DU XIXE SIÈCLE. COMBAT POUR LA LIBERTÉ DE PAROLE}

\section{Résumé}

Les caricatures sont l'une des formes d'expression artistique. Elles jouent un rôle similaire aux présentations satiriques. Certains considèrent la caricature comme l'une des formes de satire. Les origines de la caricature datent de l'époque antique. L'histoire de la caricature illustre les changements politiques tout au long de l'histoire de la civilisation. Autorités administratives dans de nombreux pays, y compris en France, menaient la lutte contre les caricatures. Ce processus fait partie de l'histoire de la censure qui trouve ses origines à l'époque romaine, et s'est ensuite développée dans le Moyen Âge chrétien jusqu'au XIX ${ }^{\mathrm{e}}$ siècle (dans certaines régions, malheureusement jusqu'aujourd'hui). Les solutions adoptées en France sont particulièrement intéressantes. Il est à noter que le phénomène caractéristique de la France n'était non seulement l'institutionnalisation de la censure, mais aussi l'existence de ses organes malgré les déclarations formelles de la liberté de parole garantie par la constitution. 
